\title{
IMPLEMENTASI METODE KOLASE DALAM MENINGKATKAN MOTORIK HALUS ANAK USIA DINI
}

\author{
Made Susenia, Ni Made Arini a, Ni Putu Sasmika Dewi ${ }^{b}$ \\ abc Institut Agama Hindu Negeri Gde Pudja Mataram \\ a madesuseni78@gmail.com a yudherini28@yahoo.co.id \\ b niputu_sasmika@yahoo.co.id
}

(Diterima: 07 Juli 2021; Direvisi: 14 Juli 2021; Diterbitkan: 26 Juli 2021)

\section{Keywords: \\ Collage Method;}

Fine Motor; Early

childhood.

\begin{tabular}{l} 
Abstract \\
\hline Improve Early Childhood Education, teachers must have high \\
creativity in delivering material using methods that make children \\
motivated to learn. One of them is the collage method which aims to \\
improve fine motor skills in early childhood. This study uses \\
qualitative and descriptive methods with data collection techniques by \\
triangulation, observation, interviews, and documentation. The \\
collage method applied at Cahaya Ananda Kindergarten uses various \\
media such as paper, seeds, cotton.
\end{tabular}

Abstrak

Meningkatkan kualitas Pendidikan Anak Usia Dini, guru harus memiliki kreativitas yang tinggi dalam menyampaikan materi dengan menggunakan metode yang membuat anak termotivasi untuk belajar. Salah sataunya dengan metode kolase yang memiliki tujuan meningkatkan motorik halus anak usia dini. Penelitian ini menggunakan metode kualitatif dan bersifat deskriptif dengan teknik pengumpulan data secara triangulasi, Observasi, Wawancara, Dokumentasi. Metode kolase yang diterapkan di Taman Kanak-Kanak Cahaya Ananda mengunakan berbagai media seperti kertas, biji-bijian, kapas.

\section{PENDAHULUAN}

Pendidikan anak usia dini juga akan membantu dan menyiapkan bekal pengetahuan anak untuk melanjutkan pendidikan ke tingkat dasar. Selanjutnya membantu anak menyiapkan dan mencapai kesiapan belajar di sekolah (Wiguna \& Ekaningtyas, 2021). Pada Pendidikan Anak Usia Dini (PAUD) anak akan mendapatkan bekal untuk menjadi pribadi yang mandiri. Dengan kemandirian tersebut akan menjadikan anak yang mudah bersosialisasi, percaya diri, memiliki rasa ingin tahu yang besar, bisa mengambil ide yang baik, mengembangkan ide yang mereka miliki, dapat beradaptasi, memiliki semangat belajar yang tinggi dan kreativitas yang tinggi (Zaenab, 2015).

Pendidikan Anak Usia Dini adalah suatu proses pembinaan tumbuh kembang anak usia lahir hingga 6 tahun 
secara menyeluruh, yang mencakup aspek fisik dan nonfisik, dengan memberikan rangsangan bagi perkembangan jasmani, rohani ( moral dan spriritual), motorik, akal pikiran, emosional, dan sosial (I. Wiguna, 2020) yang tepat dan benar agar anak dapat tumbuh dan berkembang secara optimal. Adapun upaya yang dilakukan mencakup stimulasi intelektual, pemeliharaan kesehatan, pemberian nutrisi, dan penyediaan kesempatan-kesempatan yang luas untuk mengeksplorasi dan belajar secara aktif (Zaenab, S., \& Sueca, 2019).

Menurut (Nursalam,

kemampuan motorik halus adalah kemampuan anak untuk mengamati sesuatu dan melakukan gerak melibatkan bagian-bagian tubuh dan otot-otot kecil, memerlukan koordinasi yang cermat serta tidak memerlukan banyak tenaga. Hal yang sama dikemukakan dalam (Depdiknas, 2008), bahwa kemampuan motorik halus adalah gerakan yang melibatkan bagian-bagian tubuh tertentu dan dilakukan oleh otot-otot kecil (halus) serta memerlukan koordinasi yang cermat seperti menggunting, mengikuti garis, menulis, meremas, menggenggam, menggambar, menyusun balok, memasukkan kelereng ke lubang, membuka dan menutup objek dengan mudah, menuangkan air ke dalam gelas tanpa berceceran, menggunakan kuas,crayon dan spidol serta melipat. Aspek motorik halus sangat menarik diteliti karena stimulasi yang optimal akan mempengaruhi perkembangan yang bagus untuk anak usia dini.

Aspek motorik halus pada Anak Usia Dini akan berkembang dengan baik apabila diiringi dengan metode-metode pengajaran yang menarik bagi anak
(Wiguna, 2020) Salah satu metode yang digunakan adalah dengan metode kolase.Kegiatan dengan metode kolase dapat mengembangkan keterampilan motorik halus pada anak. Metode kolase adalah metode penyusunan berbagai bahan pada sehelai kertas, kain,dan bahan-bahan berstruktur ataupun bendabenda menarik lainnya.

Kemampuan motorik halus beberapa anak di kelas B2 Taman KanakKanak Cahaya Ananda berdasarkan observasi awal terlihat kurang dilatih.Hal ini disebabkan oleh sedikitnya kegiatan terkait peningkatan motorik halus anak khususnya kolase dengan menggunakan media selain kertas yang dilakukan oleh guru, selain itu kalaupun ada kegiatan kolase, partisipasi anak-anak pada kegiatan tersebut kurang, karena media yang dipakai kertas.Beberapa anak terlihat malas-malasan atau cendrung tidak tertarik pada kegiatan tersebut. Maka dari itu peneliti mencoba menggunakan metode kolase untuk meningkatkan kemampuan motorik halus anak kelas B2. Berdasarkan masalah diatas, maka peneliti memberanikan diri untuk mengamati hal tersebut dengan penelitian yang berjudul "Meningkatkan Kemampuan Motorik Halus Anak Melalui Penerapan Metode Kolase Pada Anak Usia 5-6 Tahun di Taman Kanak-Kanak Cahaya Ananda".

\section{METODE}

Penelitian ini menggunakan metode kualitatif yaitu penelitian bersifat deskriftif dengan teknik pengumpulan data secara triangulasi/gabungan. Penelitian ini memilih lokasi di Taman Kanak-Kanak Cahaya Ananda, jalan Ki Hajar Dewantara No. 2B Bagirati kelurahan Karang Taliwang, Cakra 
Negara. Karena metode kolase yang diterapkan pada kelas B2 di Taman Kanak-Kanak Cahaya Ananda masih belum maksimal untuk meningkatkan kemampuan motorik halus anak, anakanak dalam mengikuti kegiatan tersebut masih kurang antusias, sehingga hasilnya kurang maksimal. Tehnik pengumpulan data penelitian ini yaitu: (1) Observasi, (2) Wawancara, (3) Dokumentasi.

\section{PEMBAHASAN}

Menurut

(Nursalam, 2005)kemampuan motorik halus adalah" kemampuan anak untuk mengamati sesuatu dan melakukan gerak melibatkan bagian-bagian tubuh dan otot-otot kecil, memerlukan koordinasi yang cermat serta tidak memerlukan banyak tenaga". Sedangkan (Sumantri, 2005) menyatakan motorik halus adalah pengorganisasian penggunaan sekelompok otot-otot kecil seperti jari jemari dan tangan yang sering membutuhkan kecermatan dan koordinasi dengan tangan.

Hal yang sama di kemukakan dalam (Nasional, 2003) bahwa kemampuan motorik halus adalah gerakan yang melibatkan bagian-bagian tubuh tertentu dan dilakukan oleh otototot kecil (halus) serta memerlukan koordinasi yang cermat seperti menggunting mengikuti garis, menulis, meremas, menggenggam, menggambar, menyusun balok, memasukkan kelereng kelubang, membuka dan menutup objek dengan mudah, menuangkan air ke dalam gelas tanpa berceceran, menggunakan kuas, crayon dan spidol, serta melipat.

Dalam penelitian ini yang dimaksudkan dengan motorik halus adalah segala kegiatan yang menggunakan otot halus pada bagian tubuh tertentu seperti jari-jemari tangan serta membutuhkan koordinasi yang cermat, seperti menggunting, menempel, menggambar ataupun mewarnai dan lainlain. Setiap anak dapat mencapai perkembangan motorik halus yang optimal asalkan mendapat stimulasi yang tepat, semakin banyak kesempatan, praktek dan bimbingan yang kontinyu.

Dari hasil observasi yang peneliti lakukan pada tanggal 20, 27 dan 31 Agustus 2020, diperoleh informasi terkait dengan penerapan metode kolase dalam meningkatkan kemampuan motorik halus anak.Kegiatan kolase yang dilakukan oleh siswa kelompok B2 menggunakan media kertas yang dipotong dengan ukuran kecil-kecil. Selama melakukan observasi, peneliti melihat persiapan yang dilakukan guru sebelum melakukan proses belajar mengajar. Sebelum memulai pelajaran, guru menyiapkan segala sesuatu, seperti APE, yang diperlukan selama kegiatan pembelajaran berlangsung.

Sebelum memulai kegiatan kolase, guru menyiapkan media dan peralatan lainnya yang akan digunakan. Media yang akan di gunakan adalah kertas,yang dipotong dengan ukuran kecil-kecil. Selain potongan kertas guru juga menyiapkan lem dan kertas bergambar atau berpola. Sebelum memulai pelajaran, guru juga memberikan penjelasan tentang apa saja yang akan dilakukan siswa dan bagaimana caranya melakukan kegiatan atau pembelajaran kolase tersebut. Setelah itu, guru memberi contoh kepada siswa langkah-langkah mengerjakan kolase, dari memberi lem pada kertas berpola, lalu menempel potongan kertas dengan rapi.Dan pada akhirnya guru memperlihatkan hasil dari menempel potongan kertas tersebut. Setelah itu, guru 
membagikan media dan bahan yang lain kepada setiap siswa.

Kegiatan kolase ini adalah salah satu kegiatan fisik motorik halus anak, yang bertujuan untuk meningkatkan kemampuan motorik halus anak dalam hal menempel potongan kertas dengan rapi sesuai dengan pola gambar yang diberikan.Selama kegiatan kolase berlangsung, berbagai reaksi tampak dari beberapa siswa, ada yang merasa bosan, ada yang merasa malas mengerjakannya, ada yang merasa jijik memengang lem dan lain sebagainya.

Disamping melakukan observasi, peneliti juga ingin mengetahui proses penerapan metode kolase yang diberikan oleh guru kepada peserta didik di Taman Kanak-Kanak Cahaya Ananda. Peneliti mengadakan wawancara kepada Kepala Taman Kanak-Kanak Cahaya Ananda, (Wiguna, 2021)kepada guru dan beberapa siswa terkait penerapan metode kolase di Taman Kanak-Kanak Cahaya Ananda, didukung juga oleh hasil wawancara dari beberapa informan yang terlibat dalam pelaksanaan pembelajaran metode kolase.

Ibu Ida Ayu Anom Satiani,SE. selaku Kepala Taman Kanak-Kanak Cahaya Ananda memberikan informasi mengenai kegiatan belajar mengajar di Taman Kanak-Kanak Cahaya Ananda, dimana sebelum proses belajar mengajar berlangsung, guru-guru harus menyiapkan segala sesuatu yang dibutuhkan dalam proses tersebut, berikut kutipan wawancaranya :

"Sebelum memulai kegiatan belajar mengajar, guru terlebih dahulu menyiapkan segala sesuatu yang menyangkut kedalam kegiatan pembelajaran. Yang pertama yang harus disiapkan adalah silabus, yang berisi rangkuman Kompetensi Inti, Kompetensi Daras, Indikator, dan rencana kegiatan pembelajaran selama 1 semester. Setelah membuat silabus, guru membuat kegiatan mingguan sesuai dengan tema, selanjutnya guru baru membuat rencana pelaksanaan pembelajaran harian, yang biasa disebut dengan RPPH. Dan menyiapkan media yang akan digunakan pada kegiatan pembelajaran, sesuai dengan apa yang tercantum dalam RPPH".

Hasil wawancara yang disampaikan oleh Ibu Ida Ayu Anom Satiani, SE dipertegas oleh ibu I Gusti Ayu Suswani,S.Pd. selaku wakil kepala Taman Kanak-Kanak Cahaya Ananda, sekaligus sebagai guru kelas kelompok A, terkait dengan kegiatan yang dilakukan oleh guru sebelum memulai kegiatan belajar mengajar, guru-guru harus menyiapkan media ataupun APE yang akan digunakan pada proses belajar mengajar berlangsung, guna memperlancar proses belajar mengajar tersebut, berikut kutipan wawancaranya :

"Sebelum memulai kegiatan belajar mengajar, sebaiknya guru menyiapkan bahan-bahan ajar yang akan digunakannya. Guru harus menyiapkan Rencana Pelaksanaan Pembelajaran Harian yang di singkat RPPH. Dalam RPPH tercantum tema dan sub tema, hari, tanggal dan tahun, alokasi waktu, kegiatan awal, kegiatan inti dan kegiatan akhir. Selain itu dalam RPPH juga dicantumkan bahan ajar atau media apa saja yang akan digunakan pada hari yang bersangkutan. Selain menyiapkan RPPH, guru juga menyiapkan kelas yang dapat mendukung kelancaran proses kegiatan belajar mengajar". 
Selain pemaparan dari kedua informan diatas, Ibu Ni Nyoman Surya Hartayani,S.Pd selaku guru kelas B1 dan juga Bendahara Taman Kanak-Kanak Cahaya Ananda, juga menegaskan bahwa selain menyiapkan RPPH dan mempersiapkan kelas, guru juga perlu menyiapkan strategi pembelajaran, berikut kutipan wawancaranya :

"Selain mempersiapkan Rencana Pelaksanaan Pembelajaran Harian $(\mathrm{RPPH})$, dan media guna mendukung kelancaran proses pembelajaran, guru juga perlu mempersiapkan strategi pembelajaran guna membuat peserta didik menjadi antusias, tertarik dan semangat serta fokus pada kegiatan. Di samping itu, alangkah baiknya kalau disetiap akhir kegiatan, guru mengulas kembali kegiatan yang tadi guna dapat memperbaiki dikegiatan berikutnya".

Berkaitan dengan proses kegiatan belajar mengajar di Taman Kanak-Kanak Cahaya Ananda, sebelum memasuk kegiatan inti, siswa-siswi Taman KanakKanak Cahaya Ananda terlebih dahulu melakukan baris berbaris di halaman sekolah, seperti yang di jelaskan oleh Ibu Ida Ayu Anom Satiani, SE. Berikut kutipan wawancaranya :

"Sebelum masuk kekelas, terlebih dahulu anak-anak berbaris di halaman sekolah, di isi dengan kegiatan gerak dan lagu, Tanya jawab, dan kegiatan bermain game atau permaiman motorik kasar lainnya. Setelah kegiatan tersebut, siswa-siswi berkumpul di aula sekolah untuk melakukan doa sebelum belajar secara bersama-sama. Setelah berdoa, siswa-siswi mengikuti pelajaran PNK, yaitu pendidikan nilainilai kemanusiaan. Pada pelajaran ini siswa-siswi di ajarkan tentang bagaimana bergaul atau bersosialisasi dengan teman atau orang lain. Selain itu siswa-siswi diajarkan bagaimana membangun kerjasama , dan menghargai dengan teman atau orang lain. Setelah kegiatan PNK, dilanjutkan dengan kegiatan inti yang dilaksanakan di dalam kelas masingmasing, dan di bimbing oleh guru kelas masing-masing".

Pernyataan dari Ibu Ida Ayu Anom Satiani, SE didukung juga oleh hasil wawancara dengan guru kelas kelompok B1, yaitu Ibu Ni Nyoman Surya Hartayani, S.Pd. yang menyampaikan bahwa sebelum memasuki kegiatan inti, siswa-siswi Taman Kanak-Kanak Cahaya Ananda mengikuti kegiatan PNK, setelah itu siswa-siswi melanjutkan ke kegiatan inti di dalam kelas masing-masing dan dibimbing oleh guru kelas masingmasing, dan kegiatan tersebut sesuai dengan RPPH yang sudah di buat. Berikut kutipan wawancaranya :

"Setelah mengikuti kegiatan PNK, anakanak masuk kelas masing-masing untuk mengikuti kegiatan inti, sesuai dengan RPPH yang telah di buat oleh guru. Jadi guru menyiapkan bahan ajar sesuai dengan tema dan sub tema, menyiapkan media yang akan digunakan. Selama kegiatan belajar berlangsung, guru hendaknya membuat anak merasa tertarik untuk melakukan kegiatan belajar tersebut, belajar itu hendaknya menyenangkan bagi anak, sehingga anak tidak merasa tertekan, melainkan merasa sedang bermain.dan kegiatan yang diberikan kepada anak hendaknya bervariasi, sehingga anak tidak merasa jenuh dan bosan. Dengan memberikan kegiatan yang merangsang keingintahuan anak akan membuat anak penasaran dan tertarik dengan kegiatan yang akan dilakukan. Dengan demikian anak-anak akan senang menerima pelajaran dari guru".

Pernyataan dari Ibu Ida Ayu Anom Satiani, SE dan Ibu Ni Nyoman 
Surya Hartayani, S.Pd diperjelas juga oleh Ibu Elisabeth Biri Koni, S.Pd selaku guru kelas kelompok B2 yang menyatakan bahwa kegiatan anak sebaiknya tidak menoton artinya kegiatan itu mesti bervariasi atau beragam, sehingga anak tidak merasa jenuh. Berikut kutipan wawancaranya :

"Kegiatan belajar anak TK sebaiknya bervariasi atau beragam, tidak hanya fokus ke satu kegiatan saja, karna itu akan membuat anak bosan dan jenuh.Kegiatan pun sebaiknya sambil bermain, dalam bermain itu disisipkan pembelajaran pada anak, sehingga anak tidak merasa tegang dengan pelajaran yang diterima.Selain itu kegiatan dan mediapun sebaiknya bervariasi agar anak tidak bosan.

Terkait dengan kegiatan belajar mengajar di Taman Kanak-Kanak Cahaya Ananda, Ibu Ni Made Erawati,S.Pd selaku wali kelas kelompok B3, menjelaskan bahwa kegiatan pembelajaran di Taman Kanak-Kanak Cahaya Ananda harus meliputi enam aspek perkembangan anak. Berikut kutipan wawancaranya :

“Kegiatan belajar mengajar di Taman Kanak-Kanak Cahaya Ananda harus mencakup 6 aspek perkembangan anak yang meliputi aspek norma agama, aspek sosial emosional, aspek kognitif, aspek bahasa, aspek fisik motorik dan aspek seni. Dimana keenam aspek itu akan berkembang secara berkaitan satu dengan yang lain. Keenam aspek itu harus dikembangkan setiap hari untuk mencapai perkembangan dan kematangan yang maksimal. Kegiatan aspek agama diisi dengan kegiatan pengenalan doa-doa pendek, sembahyang dan lain sebagainya, aspek sosial emosional biasanya diisi dengan kegiatan permainan yang mengutamakan kerjasama , aspek bahasa diisi dengan kegiatan penugasan ataupun praktek langsung, aspek kognitif diisi dengan berhitung atau praktek langsung, aspek fisik motorik diisi dengan kegiatan yang menggunakan fisik seperti olahraga dan lain-lain, dan aspek seni diisi dengan kegiatan bernyanyi atau membuat karya seni".

Hasil wawancara yang disampaikan oleh $\mathrm{Ibu} \mathrm{Ni}$ Made Erawati,S.Pd, dipertegas lagi oleh Ibu Elisabeth Biri Koni, S.Pd selaku guru kelas kelompok B2 yang menerangkan bahwa kegiatan-kegiatan tersebut harus dilakukan secara berkesinambungan, sehingga kemampuan anak pada keenam aspek itu dapat meningkat. Berikut kutipan wawancaranya :

"Kegiatan-kegiatan yang menyangkut enam aspek yang harus dikembangkan, sebaiknya diberikan secara terus-menerus secara berkesinambungan. Itu akan membuat anak dapat mencapai tahap perkembangan yang baik. Salah satu aspek yang paling harus dikembangkan itu adalah aspek fisik motorik, dimana aspek fisik motorik ini dibagi menjadi 2, yaitu motorik halus dan motorik kasar.Motorik halus biasanya diisi dengan kegiatan yang menggunakan atau melibatkan jari jemari atau otot-otot halus, misalnya mewarnai, menggambar dengan tehnik kolase.Sedangkan motorik kasar, biasanya diisi dengan kegiatan yang melibatkan tangan atau kaki".

\section{Dilain kesempatan Ibu Ni Nyoman} Surya Hartayani,S.Pd selaku guru kelas kelompok B1 juga menjelaskan bahwa aspek motorik halus anak harus dikembangkan juga secara optimal, dan salah satu metode yang digunakan adalah 
dengan menggunakan kegiatan kolase. Berikut kutipannya :

"Aspek motorik halus juga harus dikembangkan juga secara optimal, dan salah satu metode yang digunakan adalah dengan menggunakan kegiatan kolase.Kegiatan kolase ini memerlukan konsentrasi untuk mendapatkan hasil yang maksimal.Media yang digunakan dalam kegiatan kolase ini bermacammacam, seperti kertas, kapas, serutan
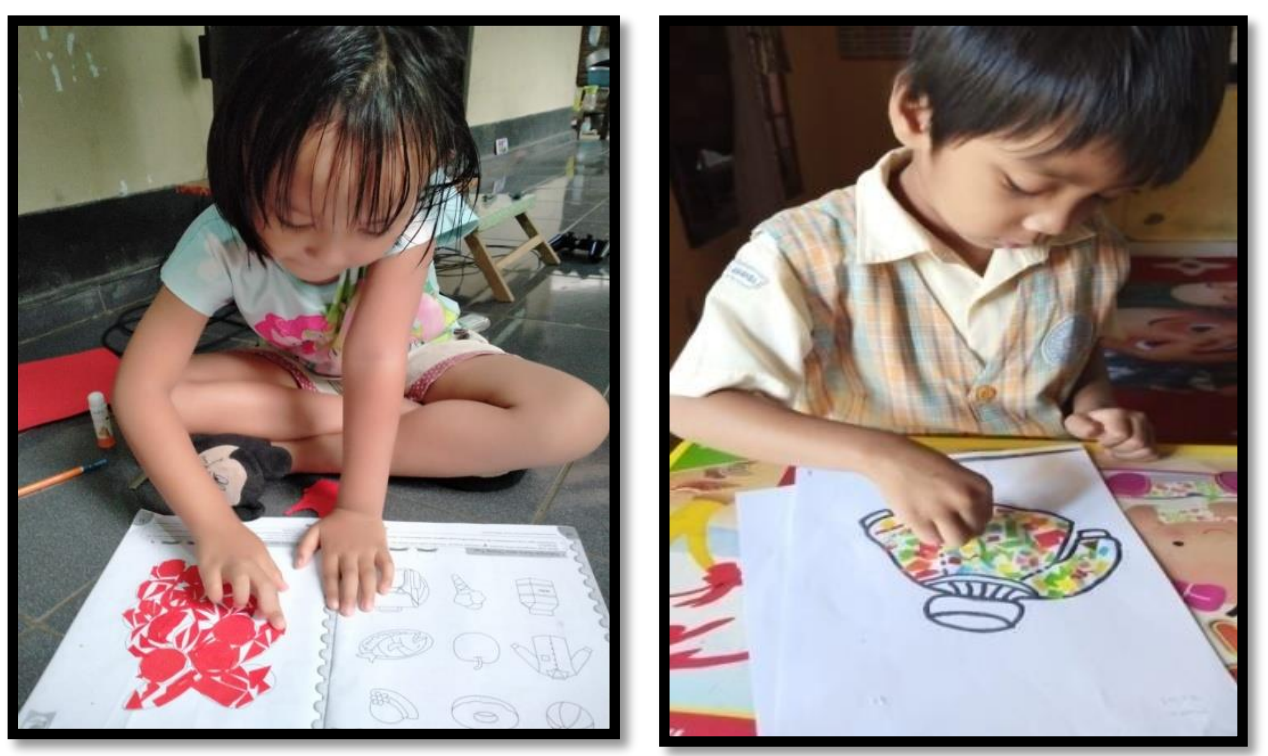

Gambar 3.1 Media yang digunakan untuk kegiatan kolase

Dari beberapa hasil wawancara diatas, dapat ditarik kesimpulan bahwa kegiatan belajar mengajar di Taman Kanak-Kanak Cahaya Ananda, didahului dengan menyiapkan segala sesuatu yang akan digunakan dalam kegiatan belajar mengajar, persiapan tersebut tercantum dalam Rencana Pelaksanaan Pembelajaran Harian atau disingkat RPPH. Kegiatan belajar mengajar di Taman Kanak-Kanak Cahaya Ananda, mencakup 6 aspek yang perkembangan yang harus dicapai secara maksimal.Ke 6 aspek tersebut adalah aspek agama dan moral, aspek sosial emosional, aspek kognitif, aspek bahasa, aspek fisik motorik dan aspek seni.Aspek motorik di bagi menjadi 2, yaitu motorik

pensil, kacang-kacangan, daun kering, dan lain sebagainya.Namun yang paling sering digunakan adalah kertas, karna mudah di dapat dan tersedia di sekolah.Kegiatan kolase tidak dilakukan setiap hari, karena ada kegiatan motorik halus lainnya seperti mewarnai, menggambar sederhana, meronce, menggunting pola sederhana dan lain sebagainya".

kasar dan motorik halus.Salah satu metode yang digunakan dalam mengembangkan kemampuan motorik halus anak adalah metode kolase.penerapan metode kolase di Taman Kanak-Kanak Cahaya Ananda tidak dilakukan setiap hari, karena masih ada kegiatan lain yang dapat meningkatkan kemampuan motorik halus anak sepeti mewarnai, menggambar, meronce, menggunting dan lain sebagainya. Metode kolase yang diterapkan di Taman KanakKanak Cahaya Ananda menggunakan berbagai media seperti kertas, kapas, serutan pensil, kacang-kacangan, daun kering dan lain sebagainya. 


\section{SIMPULAN}

Penerapan metode kolase di Taman Kanak-Kanak Cahaya Ananda diawali dengan persiapan yang tercantum dalam RPPH. Kegiatan belajar mengajar di Taman Kanak-Kanak Cahaya Ananda mencakup 6 aspek perkembangan, salah satu aspek tersebut adalah motorik halus. Untuk mencapai perkembangan aspek tersebut diperlukan cara atau metode yang diterapkan pada kegiatan pembelajaran. Salah satu metode yang digunakan dalam mengembangkan kemampuan motorik halus anak adalah metode kolase. Penerapan metode kolase di Taman Kanak-Kanak Cahaya Ananda tidak dilakukan setiap hari, karena masih ad kegiatan lain yang dapat meningkatkan kemampuan motorikhalus anak. Seperti mewarnai, menggambar, meronce, menggunting, dan sebagaimya. Metode kolase yang diterapkan di Taman KanakKanak Cahaya Ananda mengunakan berbagai media seperti kertas, biji-bijian, kapas, dan lain-lain. Namun media kertas yang paling sering dipakai

\section{DAFTAR PUSTAKA}

Kurikulum dan Hasil Belajar Pendidikan Anak Usia Dini, Jakarta: Pusat Kurikulum (2008).

Ida Bagus Alit Arta Wiguna, K. A. T. R. D. (2020). Strategi Guru Dalam Peningkatan Mutu Pembelajaran Etika Hindu. Jurnal Penjaminan Mutu, 6(2), 210-220. https://doi.org/DOI: http://dx.doi.org/10.25078/jpm.v6i2.14
Nasional, D. P. (2003). Undang-Undang Nomor 20 Tahun 2003 Tentang Sistem Pendidikan Nasional. Jakarta: Depdiknas, 35.

Nursalam. (2005). Perkembangan Dan Konsep Dasar Perkembangan Anak Usia Dini. Jakarta: Universitas Terbuka.

Sumantri. (2005). Model Pengembangan Keterampilan Anak Usia Dini. Jakarta Uiversitas Terbuka.

Wiguna, I. B. A. A., E Ekaningtyas, N. L. D. (2021). STRATEGI ORANG TUA DALAM MENDAMPINGI ANAK USIA DINI BELAJAR DARING DI RUMAH. Pratama Widya: Jurnal Pendidikan Anak Usia Dini, 6(1), 8695.

Wiguna, I. (2020). POLA ASUH DALAM PENUMBUHKEMBANGAN

KARAKTER TOLERANSI ANAK USIA DINI DILINGKUNGAN MINORITAS. Prosiding STHD Klaten Jawa Tengah.

Wiguna, I. B. A. A. (2021). Kepemimpinan Kepala Sekolah PAUD Di Masa Pandemi Covid-19. In Prosiding Seminar Nasional Institut Agama Hindu Negeri Tampung Penyang Palangka Raya, 1(1), 221-233.

Zaenab, S., E Sueca, I. N. (2019). MENCERDASKAN ANAK BANGSA MELALUI PENDEKATAN PEMBELAJARAN PENDIDIKAN ANAK USIA DINI. PRATAMA WIDYA: JURNAL PENDIDIKAN ANAK USIA DINI, 3(1).

Zaenab, S. (2015). Profesionalisme Guru PAUD Menuju NTB Bersaing:(Pengantar Manajemen Pendidikan, Praktik, Teori, dan Aplikasi. Deepublish. 